\title{
Organisational culture in knowledge creation, creativity and innovation: towards the Freiraum model
}

Journal of Information Science $1-14$

(C) The Author(s) 2013

Reprints and permissions: sagepub.co.uk/journalsPermissions.nav DOI: $10.1177 / 016555151000000$ jis.sagepub.com

Note: this is the version of the article accepted for publication. The published version (DOI 10.1 177/016555/513508356) was made available OnlineFirst on 22 ${ }^{\text {nd }}$ November 2013 and can be downloaded from the publisher's web site at: http://jis.sagepub.com/content/early/2013/I I/22/016555 I5 I3508356.full.pdf+html

\section{Jan Auernhammer}

Centre for Social Informatics, Edinburgh Napier University, UK

\section{Hazel Hall}

Centre for Social Informatics, Edinburgh Napier University, UK

\begin{abstract}
This paper draws on findings from an in-depth case study of practices related to the meeting of organisational goals pertinent to knowledge creation, creativity and innovation performance. Overall a mixed methods approach that used both quantitative and qualitative data was adopted in empirical research conducted within a large German manufacturing firm. A quantitative analysis of survey data highlighted factors necessary to nurture an environment conducive to knowledge creation, creativity and innovation: the organisation should be open to change; encourage and value free communication and new and/or unusual ideas; tolerate mistakes; and nurture intrinsically motivated staff. It should be supported by leaders who promote these characteristics as shared values, while challenging and empowering their staff to generate new ideas in a drive to further innovation. Further analysis of focus group and interview data in the same case study identified three main determinants that underpin knowledge creation and creativity: (I) structured "space" that creates expertise and experience of individuals while working in routine; (2) willingness to innovate: individuals' propensity to experiment with ideas, even at risk of failure; and (3) authorised and dedicated "space" designated specifically for individuals to explore of new ideas ("Freiraum"). These findings have contributed to the development of a new articulation of the organisation of creativity and innovation. It draws on established concepts from the domain of knowledge and creativity management, and extends these to deepen our understanding of how aspects of organisational culture, including leadership and social conditions, influence organisational performance in terms of (a) improving knowledge creation processes related to creativity, and (b) fostering innovation.
\end{abstract}

\section{Keywords}

creativity, Freiraum, innovation, knowledge creation, knowledge management, learning, organisational culture, organisational learning

\section{Introduction}

This paper explores knowledge and creativity management issues related to organisational culture. These include leadership and social conditions, and their influence on practices of creativity and innovation as individuals interact within broader organisational contexts. The main findings presented here derive from a large empirical study conducted within a German automotive manufacturer between 2007 and 2011. Overall the study identified three strata of influence:

Corresponding author:

Hazel Hall, Centre for Social Informatics, Edinburgh Napier University, 10 Colinton Road, Edinburgh EHI0 5DT, UK h.hall@napier.ac.uk 
those related to (1) the macrostructure as evident in culture of the organisation; (2) social interactions conducted between individuals; and (3) individual cognitive processes. This paper is mainly concerned with the first of the three.

The findings are prefaced by a literature review that considers the treatment of organisational culture in the extant literature as a facilitator of (or hindrance to) knowledge and creativity management. It also explains how organisational culture is incorporated into models of $\mathrm{KM}$, and into frameworks that consider knowledge creation, creativity and innovation. Of particular interest is the work of Nonaka and Takeuchi [1], and Nonaka and Konno [2], and how this might be extended through the introduction of a set of linked concepts that includes reference to a phenomenon identified as "Freiraum". The work presented responds to a broad call for a closer examination of links between knowledge, innovation and performance to identify the organisational circumstances under which KM initiatives lead to improved results [3].

\section{Literature review}

\section{I. Knowledge management and organisational culture}

While understandings of the term "knowledge management" (KM) are diverse and much debated [4, p. 185], the broad goals of $\mathrm{KM}$ focus on the improvement of organisational performance, whether or not the organisation in question articulates this by deploying the discourse of KM (for example, [5, pp. 5-7]; [6, pp. 10-13]). For instance, in the context of manufacturing industry, KM processes such as efforts towards improved information and knowledge sharing are aligned to the goals of new knowledge creation to support innovation (for example, [3], [7]).

Just as there is general agreement on its broad purpose, the extant literature of the domain has discussed at length, and repeatedly, the many barriers to effective KM, particularly as related to information and knowledge sharing (for example, [8], [9]). Organisational culture is frequently cited as one such barrier (for example, [10, pp. 192-3] [11, p. 181]). Alternatively, in cases where a supposed "knowledge culture" exists, organisational culture is valued as an enabler [4, p. 183 and p. 185].

Interest in the relationships between organisational culture and knowledge management has generated a number of studies and theoretical contributions [4]. Often the treatment of these themes is, however, generalised (for example, [12]), with scant regard paid to the specifics of "organisational culture" and what it might comprise beyond "organizational values, norms, unwritten rules and procedures" [13, p. 238]. Equally others have identified the mistaken implicit assumption of earlier studies that organisational culture is uniform across the whole organisation (i.e. literally a single organisational culture) [4, p. 197], and a stable phenomenon [5, p. 238]. A further drawback of this body of literature is that many of the more detailed studies fail to investigate the impact of organisational culture on specific KM processes other than knowledge sharing [4, p. 197]. Earlier reviews have identified that there is opportunity, for example, to make contributions related to processes such as new knowledge creation [4, p. 191], including creative processes.

A further problem relates to how the summarised output of studies of organisational culture and its influence on knowledge and creativity management are presented. This often take the form of lists of conditions and values - such as trust, openness, tolerance of mistakes, encouragement of risk taking, employee autonomy, support of teamwork - as general enablers (for example [4, p. 191]). Where organisational culture is incorporated into general models and frameworks of $\mathrm{KM}$, it is often treated as a top level heading alongside people, processes, technology, and as a component of "the organisation". For example, Mueller's 2012 model "The interrelationship of corporate culture, cultural knowledge and knowledge management" [4, p. 197] only goes to the level of "Cultural knowledge: assumptions, values and manifestations". It is unsurprising that this is the case given the breadth of concepts and processes that KM comprises. Added to this is the difficulty of modelling a comprehensive picture that is able to both describe KM, and prescribe the outcome of any particular interventions. At the other extreme, detailed models and frameworks of KM that focus on a particular aspect (for example Boisot's I-Space KM model, with its emphasis on information and knowledge per se [14]) are limited because (unsurprisingly) they are not comprehensive enough. It is perhaps for this reason that amongst the most compelling models of KM are those that promote the importance of connections (for example, [15]) on the basis that knowledge resides with individuals and their relationships with others, and is embodied within organisations as such.

It is also worth considering here how case studies published in the practitioner press treat the issue of organisational culture and KM. Often here the umbrella term "organisational culture" is simply applied loosely without detailed explanation, and may be deployed as a neutral term for less desirable organisational characteristics such as corporate power struggles [11], [16]. A close reading of such studies demonstrates the degree to which local contexts determine 
the degree of success of activities targeted at improving KM and its desired outputs [17]. However, practitioners who hope to draw on examples of good practice for their own implementations will be disappointed because the actualities of published case studies in the organisations in question do not match their own local environments. "Black box" case studies (for example, [18, [19], [20]) may offer cheery accounts of successful practice - but this may not necessarily be replicated beyond the locus of the reported study.

\subsection{Models of new knowledge creation, innovation and organisational culture}

A number of models and frameworks, emanating from a wide range of subject domains, provide detail on particular processes of KM. Those that include discussion of new knowledge creation and innovation are summarised in Table 1 below.

Table I. Models that incorporate concepts of knowledge, creativity and innovation

\begin{tabular}{ll}
\hline Models & Concepts \\
\hline $\begin{array}{l}\text { Communities of practices, social } \\
\text { networks and online communities }\end{array}$ & $\begin{array}{l}\text { Communities of practice and the creation of } \\
\text { knowledge, creativity and innovation }\end{array}$ \\
Creative and innovative systems & $\begin{array}{l}\text { Disciplines, practices, structures and organisation of } \\
\text { creativity and innovation }\end{array}$
\end{tabular}

Distributed knowledge systems

Information-based system

Knowledge conversion

(SECl model and $\mathrm{Ba}$ )

Knowledge-centric systems

Learning systems

(single and double loop learning)

Open and co-creating systems

Self-producing systems

(autopoietic systems)

Sense making and organising Spatial constructed systems (autopoietic systems)

Systems of shared meaning

System-thinking system

Viable systems

(self-referential systems)
Knowledge-based view of the organisation, disciplines, practices and structure of knowledge creation Organisational construction of knowledge and meaning

Tacit knowledge as source of creativity and innovation; spatial knowledge and shared context creation within the organisation; organisational knowledge creation

Learning about learning in organisations

Reflective learning about action and governance to continuous improve (first and second order cybernetics)

Open innovation, user groups and co-creation to generate customer and user innovation

Autopoietic systems of knowledge creation and innovation

Sense making and organising from process Spatial construction of organisation

Influence of culture (structure) on process and outcome

Organisational capabilities and disciplines of learning Recursive interaction with environment to adoption of changing environment
Key authors and Sources

Amin \& Roberts [2I], [22];

Davenport \& Hall [23]; Hall \&

Graham [24]; Wenger [25];

Wenger, McDermott \& Snyder [26]

Amabile [27], [28]; Bendixen [29];

Csíkszentmihályi [30], [3I]; Jaworski

\& Zurlino [32]; Nooteboom [33];

Sawyer [34]; Sutton [35]; Teece

[36]; Tidd \& Besant [37];

Woodman, Sawyer \& Griffin [38];

Zhou \& Shalley [39]

Grant [40]; Tsoukas [4I]; Von

Krogh \& Roos [42]

Choo [43]

Nonaka \& Takeuchi [I]; Nonaka, Toyama \& Hirata [44]

Stonehouse \& Pemberton[45]; Pemberton \& Stonehouse [46], [47]

Argyris \& Schön [48]; Argyris [49]

Chesbrough[50], [5I]; Von Hippel [52], [53]; Prahalad \& Ramaswamy [54]; Ramaswamy \& Gouillart [55; Bakken, Hernes \& Wiik]

[56], [57]; Hernes \& Bakken [58]; Hernes [59]; Luhmann [60]; Maula [6I]; Magalhães \& Sanchez [62]; Zeleny [63], [64]

Daft \& Weick [65]; Weick [66]

Amin \& Roberts [2I];Nonaka, Toyama \& Hirata [44]; Hernes [67], [68]; Crang \& Thrift [69]; Thrift [70], [7I]

Smircich [72]

Senge [73]

Beer [74], [75] 
As is the case of models and frameworks of KM in general, the models that cover the processes associated with new knowledge creation and innovation, such as those summarised in Table 1 above, also attract criticism for being too general [76, p. 2]. Nevertheless, taken together, these models provide important insight into how the generation of new knowledge through thinking (the process of creativity) is organised to formulate novel and valuable ideas which can then be institutionalised and exploited (the outcome of creativity as innovation). It should still be recognised, however, that the explanations of creativity and innovation offered by these models are very complex. They take into account a large number of personal, social and contextual influences, to explain how individual, group and organisational processes are supported and constrained. The concept of "intelligent complex adaptive systems" as introduced by Beer [77] and developed by others (for example [78]), for example, is appropriate nomenclature to describe organisations as living, self-organising entities that comprise individuals who negotiate relationships within communities to create new knowledge for innovation operating, and are subject to a variety of positive and negative influences on their work.

The terms "creativity" and "innovation" also pose problems in the literature. They are often used interchangeably to describe both (1) processes that result in something novel and valuable, and (2) the outcomes of such processes that are novel and valuable in themselves (for example a product, service, organisational structure or administrative system). The loose treatment of the two terms together is understandable given that innovation as a process necessarily incorporates creativity: the act of innovation includes the implementation of the initial creative idea. In addition, as an initial creative idea is shaped and developed during an implementation, it is often the case that new ideas are prompted. So, for example, creative thinking may become as part of an innovation process when those charged with an implementation are faced with an unexpected problem and are forced to find ways to solve it. Thus innovation is routinely a creative process in itself.

Another characteristic that this body of literature shares with the more "mainstream" KM publications is the identification of a number of key enabling factors, in this instance applied to organisational capacity for new knowledge creation and innovation. Those identified at the level of the organisation (the focus of this paper) correspond with the desirable elements of a culture for engendering good KM practice. These include, for example, access to information and knowledge resources through effective information and knowledge sharing behaviours, open communication practices and established routines (for example, [40]). Added to these are other elements of the organisational infrastructure that bear an influence. Amongst these are intangibles - such as organisational leadership and vision [37] [44], commonly shared representations of meaning [72] and conditions that promote a sense of trust [27] - as well as more concrete conditions that include the nature of the physical environment [38, p. 296], and the resources of time and money [28]. Often these factors cannot be "bought in", but rather built, developed and cultivated over time [36].

Amongst the models listed in Table 1, Nonaka and Takeuchi's well-established and oft-cited knowledge conversion model [1] is of particular interest to the study reported in this paper, not least because it considers knowledge creation as an organisational capability that comprises a social process in which knowledge is transformed through interactions. This model closes the gap between individual and group processes at the micro level, and those at the organisational, or macro, level. Built on the Japanese premise that knowledge in the workplace is principally collectively owned group knowledge (a different cultural perspective than that which is pervasive in the West [79]), the model describes four stages $^{1}$ through which knowledge is acquired, shared, developed and integrated, moving between tacit and explicit forms, to create new insight. These stages are labelled (1) Socialisation, where knowledge is created through social interaction; (2) Externalisation, where knowledge is articulated and codified into a tangible format; (3) Combination, where discrete pieces of knowledge are combined to create new knowledge; and (4) Internalisation, where new knowledge becomes embedded in the minds of knowers. Although Nonaka and Takeuchi do not use the term explicitly, this is an autopoietic cycle of both organisational and individual and group interactions, where the former is labelled "structure" and the latter "process" in autopoietic terms (as discussed in other models noted in Table 1 above, for example [33], [64]).

With Konno in 1998, Nonaka introduced the concept of "Ba" to the model of knowledge conversion [2]. This has since been further developed (for example, [44], [80]). "Ba" relates to mental and social space in constant motion in which shared context and new knowledge is created [44, pp.34-35]. Unlike "ordinary" space, it has been argued that Ba, in its various forms, can overcome physical and temporal restraints. It does so in each quadrant of the SECI model [2 pp. 46-47]:

- Originating $B a$, relevant to Socialisation, is the space where individuals share feelings, emotions and experiences 
- Interacting $B a$, relevant to Externalisation, is the space where individuals learn about the mental models of others, and reflect and analyse their own collectively

- Cyber $B a$, relevant to combination, is the space for interacting in the online environment

- Exercising $B a$, relevant to internalisation, is the space where explicit knowledge becomes tacit

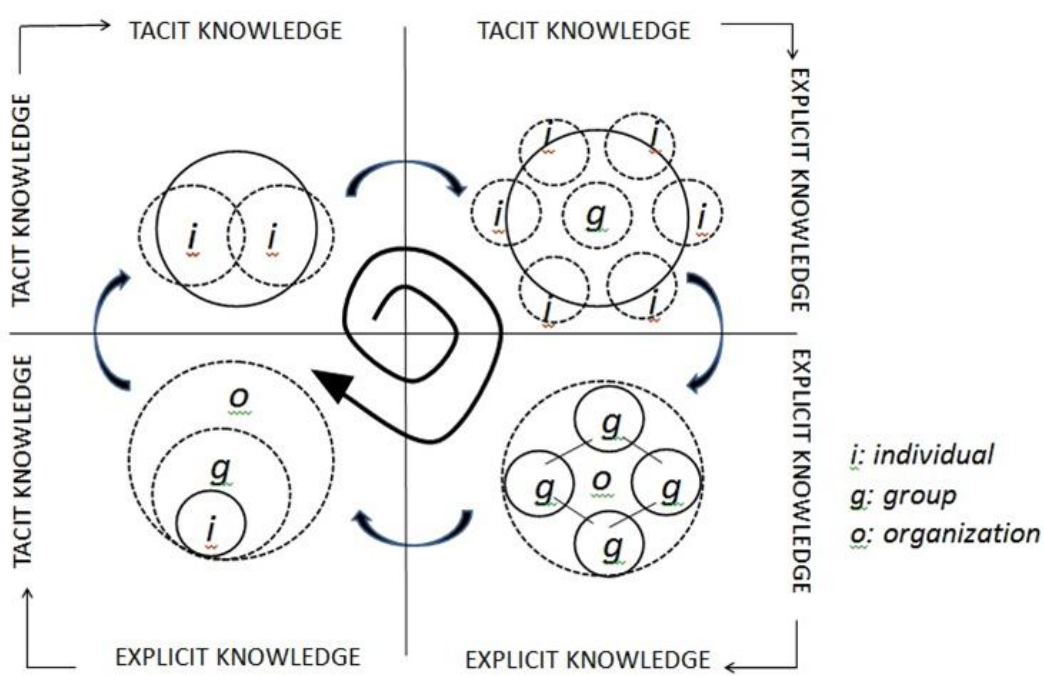

Figure I: Spiral evolution of knowledge conversion and self-transcending process (Source: [2, p. 43])

The concept of $\mathrm{Ba}$ is pertinent to the study reported here because this new work explores the enabling conditions that relate to organisational culture, such as leadership (in terms of knowledge vision), noted as important to Originating Ba [2, p. 46]. In addition, Cyber Ba is said to influence organisational culture [2, p. 47]. This earlier work is also relevant to the empirical study reported in this article given the new insight it provides on the concept of "space" (as will be explained below).

While the SECI model neatly explains routes for knowledge creation within a shared social context, Bereiter [81, pp. 160-161] notes it falls short on four accounts related to creativity. One of these is directly related to the organisational context: the model has little to say about the production, management, improvement or application of knowledge abstracted from practice. Others have argued similarly that the model does not provide an adequate explanation of innovation (for example [82], [83]). For instance, although it explains how pre-given conditions and knowledge can be represented, it fails to tie these to the innovation process [83]. Furthermore, the SECI model does not take into account complexities identified by other scholars, such as the fact that creative ideas are often routinely rejected in organisations [84] [85].These findings point to the need to extend the model to enhance the explanation of desirable conditions and processes for creativity and innovation. The report of the empirical study as related below helps address this need.

\section{Research design: site selection, data collection, and analysis}

The findings reported here derive from a single in-depth case study investigated between 2007 and 2011. The site for data collection is a large German company characterised as enjoying a complex, dynamic and evolving organisational culture: in 2011 it employed just over 270,000 staff across six main divisions. As a world-leading automotive manufacturer, the company has a long history of innovation that stretches back to the late nineteenth century.

Data for the study were gathered from in three main stages from 2007/8 onwards when the first author worked for the company as a Research Associate:

- by survey: 201 participants from across a range of business functions responded;

- from two focus groups that comprised 18 development department staff (total);

- in interviews with 46 employees who work in innovation management functions. 
The survey was designed to investigate the organisational context within the company, and focused on gathering data to assess the experience and perceptions of employees from across a range of functions and different career stages within the company. Administered in German, the respondents were asked to rate 112 statements on a four point Likert scale group within sections, as shown in Table 2 below.

Table 2. Survey sections (key concepts/intellectual bins)

\begin{tabular}{|c|c|c|}
\hline Survey section & $\begin{array}{l}\text { Survey section heading (related to key concept } \\
\text { or 'intellectual bin') }\end{array}$ & Sample statement (translated from German) \\
\hline B & Information and explicit knowledge & $\begin{array}{l}\text { We continually collect information about our } \\
\text { products }\end{array}$ \\
\hline C & Tacit (implicit) knowledge & $\begin{array}{l}\text { We are adequately trained to develop the skills } \\
\text { and expertise required for our work }\end{array}$ \\
\hline $\mathrm{D}$ & Vision and leadership style & $\begin{array}{l}\text { Our leaders balance our work between } \\
\text { operational tasks and time to think }\end{array}$ \\
\hline $\mathrm{E}$ & Organisational behaviour and climate & $\begin{array}{l}\text { We have open communication in our } \\
\text { organisation }\end{array}$ \\
\hline $\mathrm{F}$ & Organisational structure and workplace & $\begin{array}{l}\text { Our organisational set-up allows us to network } \\
\text { easily with staff from other departments }\end{array}$ \\
\hline G & Resources & $\begin{array}{l}\text { We have access to financial resources to } \\
\text { support experimentation }\end{array}$ \\
\hline $\mathrm{H}$ & Infrastructure and communication & $\begin{array}{l}\text { Most of our team communication is done over } \\
\text { e-mail }\end{array}$ \\
\hline 1 & Knowledge creation routines & $\begin{array}{l}\text { We regularly gain work experience, in practice } \\
\text { and on-site }\end{array}$ \\
\hline J & Creativity routines & $\begin{array}{l}\text { We create innovative solutions by viewing } \\
\text { problems from different perspectives }\end{array}$ \\
\hline
\end{tabular}

Of 320 surveys distributed, 201 were completed, giving a response rate of $63 \%$. A factor analysis of the survey responses as related to the ten statements on innovation performance (for example "We create innovative solutions by viewing problems from different perspectives") provided a macro-level gauge of participant perceptions. Using the Pearson correlation coefficient analysis (PCA) function in SPSS, relationships between the key determinants were revealed.

The findings on innovation performance (amongst others related to wider aspects of the study) as derived from the quantitative analysis of the survey data were then presented at the two focus groups. Here they served as a stimulus for group discussion (following the technique advocated by Barbour [86]). In two sets, the eighteen focus group participants verified the survey findings and discussed the impact of the macrostructure on individual behaviours and interactions (both their own, and that observed in others) as related to new knowledge creation, creativity and innovation. Both focus group discussions were recorded for later analysis.

The forty-six semi-structured interviews which followed provided a further opportunity to discuss the emergent themes in greater depth, in this instance for between 30 to 40 minutes on a one-to-one basis with (mainly) senior managers whose job remit included responsibility for innovation per se, or innovation management. These managers worked in a range of departments including innovation management, research, development, production, marketing, and after-sales. The interviewees provided a diverse range of personal and contextually rich narratives in response to a number of prompts that took the form of basic questions. Emergent themes thus came to the fore in an inductive manner. All but five of the interviewees gave permission for the interviews to be recorded. The interview data were subsequently explored and analysed alongside the other qualitative data using NVivo.

Coding and cognitive mapping of the qualitative data from the focus groups and interviews generated valuable output that was reformulated as patterns [87] [88] [89]. The total of nine patterns generated from the data collected described the situations in which creative ideas emerge within interactions of individuals at the micro level, as bound within the broader social structures of the macro level. They helped to explain the impact of cultivated behaviours on group interactions as related to team creativity and organisational innovation. Considered together, the patterns contributed to the design of a system model of the phenomena under investigation. Attention was paid here to interactions that related to (a) shared behaviours at the macro level of the organisation and (b) situated interactions performed between individuals and small groups at the micro level, reflecting the duality of structure [90] and tenets of organisational 
autopoiesis theory (for example, [62] [91]). The pattern analysis identified components of organisational culture as determinants for new knowledge creation, creativity and innovation. From this can be offered practical advice that applies across a number of contexts.

Following the analysis of the empirical data from the three data collection exercises (the survey, the focus groups, and the interviews) the results were disseminated within the case study organisation in a series of presentations. These presentations provided an opportunity to verify the research findings and confirm their relevance. They also gave the staff a chance to reflect on the implications of the study's findings in practice.

\section{Findings: key influences of organisational culture on creativity and innovation}

Amongst the main findings of the study (and the focus of this paper) is new insight into how organisational culture (including leadership and social conditions) influences practices of creativity and innovation as individuals interact within the broader organisational context of the company.

Table 3. Linear dependency (PCA) between factors of organisational context and innovation

\begin{tabular}{lll}
\hline No. & Influence factors on innovation & $r$ \\
\hline I. & Leadership style (D.I) & 0.49 \\
2. & Organisational behaviour I (E.I) (openness, motivation and values) & 0.48 \\
3. & Creative methods and interdisciplinary working (J.I) & 0.48 \\
4. & Innovation information (B.I) & 0.4 I \\
5. & Organisational and team structure (F.II) & 0.38 \\
6. & Knowledge creation - face-to-face conversations (I.III) \\
7. & Knowledge creation processes (I.I) & 0.36 \\
8. & Organisational behaviour II (E.II) (mistakes and problem behaviour) \\
9. & Management of implicit knowledge (C.I) & 0.34 \\
I0. & Workplace (F.I) & 0.33 \\
II. & Business support information (B.II) & 0.3 I \\
I2. & Vision communication (D.II) & 0.29 \\
I3. & Information infrastructure (H.I) & 0.27 \\
I4. & Knowledge and time resources (G.II) & 0.23 \\
I5. & Knowledge creation - information system (I.II) \\
I6. & Financial and information resources (G.I) \\
\hline
\end{tabular}

The quantitative analysis of the survey data revealed the characteristics of an environment that is conducive to innovation performance. In total sixteen factors of organisational context were identified as having an impact, as can be seen in Table 3. The two most significant of interest to the themes of this paper - due to its focus on organisational culture - are Leadership style and Organisational behaviour I: openness, motivation and values, both of which show close to strong effect ${ }^{2}$. Also of interest is the category placed eighth: Organisational behaviour II: mistakes and problem behaviour. The factors noted in Table 3 were combined through a further factor analysis to build groups of factors, which were then subsequently correlated with performance factors in further PCAs. Of interest to the main themes of this paper is the combination of Leadership style, Organisational behaviour I, and Organisational behaviour II. Grouped together these can be conceived as influences of organisational culture. They depend closely on one another, as shown in the high Pearson's coefficient figures in Figure 2. 


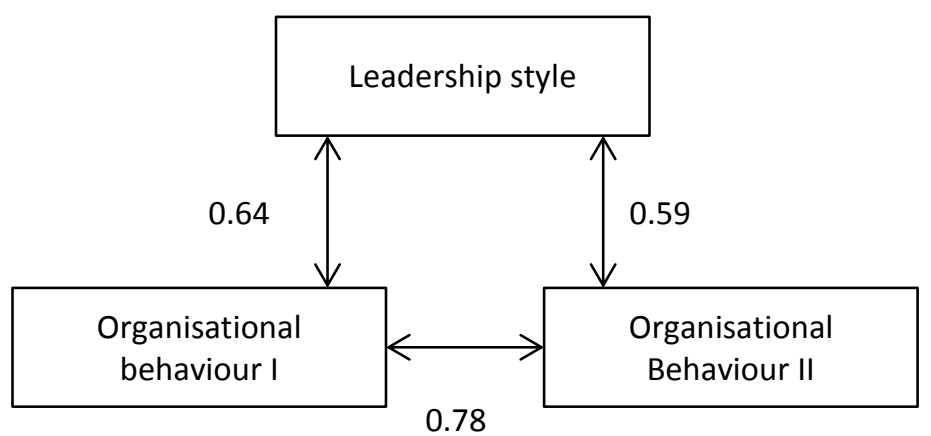

Figure 2. Correlation coefficients of the organisational culture group

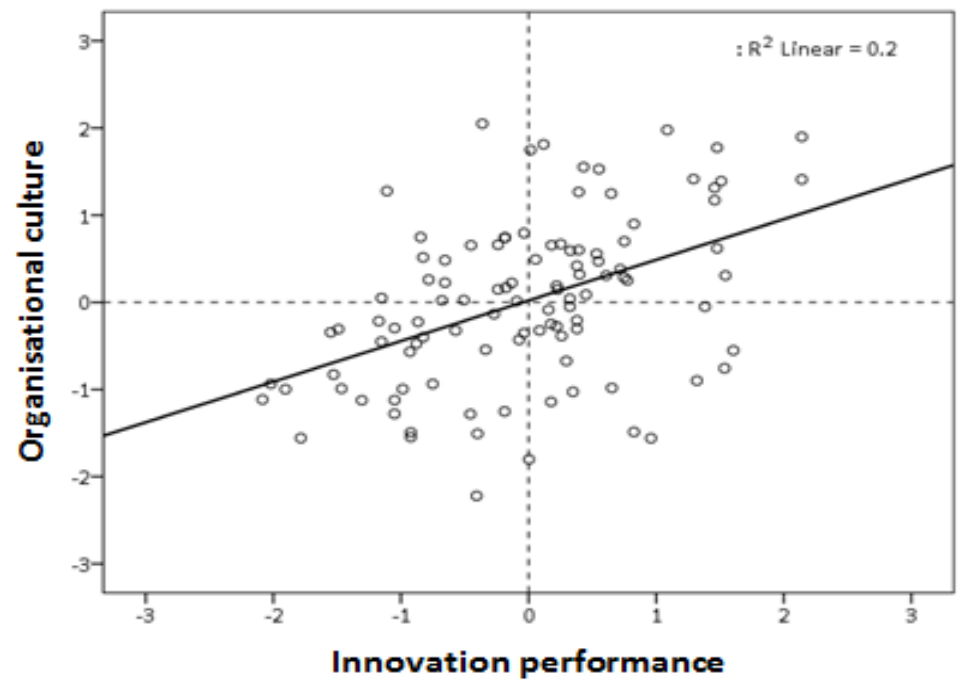

Figure 3. The relationship between organisational culture and innovation performance (PCA)

When the group Pearson coefficient is then calculated to establish the relationship between organisational culture and innovation performance a high medium score is revealed $(\mathrm{r}=0.46)$. This relationship can also be plotted as a graph, as shown in Figure 3. Here the points represent the data subjects who provided survey responses that could be analysed to assess this relationship (150 in total). In general, individual perceptions of "poor" organisational culture fit with perceptions of "low" innovation performance. Equally "good" organisational culture fits with "high" innovation performance. From the analysis of the survey data it was also possible to list individual organisational behaviours and leadership practices that generate social space that is conducive to new knowledge creation and creativity. Those with strong medium influence are highlighted in Table 4.

Table 4. Ranked value of organisational characteristics that influence innovation

$\begin{array}{lr}\text { Characteristic of the organisation } & r \\ \text { It is open to change } & 0.48 \\ \text { Its leaders challenge staff to create new ideas } & 0.45 \\ \text { Its leaders empower staff to generate new ideas } & 0.4 \text { I } \\ \text { It is populated by staff who are intrinsically motivated } & 0.39 \\ \text { It values free communication } & 0.36 \\ \text { It promotes a shared vision and goals } & 0.35 \\ \text { It practises its shared values } & 0.3 \text { I } \\ \text { Its leaders practise its shared values } & 0.30 \\ \text { Its leaders balance time to work and to think } & 0.28\end{array}$


It encourages risk-taking

It encourages a positive atmosphere 0.25

It values trust 0.25

Its leaders value new and/or unusual ideas 0.25

Subsequent discussion in the focus groups and interviews confirmed the importance of these factors. This contributed to the final data sets from which nine patterns of the larger study emerged:

(1) Individual knowledge creation

(2) Co-creation

(3) Vision, strategy and leadership

(4) Innovation willingness and reaction to mistakes

(5) Ambiance and social support

(6) Regulatory, social and cognitive influences on time spaces

(7) Communication behaviour

(8) Spaces of knowledge creation

(9) Change in work pattern and routines

The patterns provided insight into how organisational culture may be a support for knowledge creation, creativity and innovation. In particular Pattern 3 revealed how leadership influences creativity, and Pattern 4 the same for innovation willingness ${ }^{3}$. Pattern 3 revealed how shared leadership values challenge and empower workers to be creative. Pattern 4 showed that the social reward of appreciation by leaders in an environment where there is open communication, low levels of stress, and high degrees of professional autonomy contribute to individual innovation willingness. Findings on collective innovation willingness were also made evident in Pattern 4. Again openness (in terms of communication and to the concept of change) is shown to be highly valued. Perhaps of greater interest here, however, is the question of risk taking and mistakes, and the organisation's reaction to these. If mistakes are not tolerated, and staff are unable to learn from mistakes, then opportunities for new knowledge creation, creativity and innovation will be lost as the organisation becomes entrenched in "safer" work practices.

When the study findings on organisational leadership and social conditions from the survey, focus groups and interviews are taken together, it can be seen that there is a strong thematic thread related to a form of work-related freedom as a pre-condition for creativity. There is no English term to encompass the actual nature of the freedom identified. Hence the introduction of the German term "Freiraum" to the discussion. Literal translations of Freiraum include "free space", "free room", or "free field". However, Freiraum can be more than a physical space: the German dictionary Duden online provides a definition that translates as "Opportunity to develop one's own strength and ideas

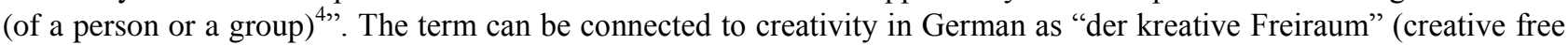
space), emphasising the human context. Thus Freiraum can represent a space that is produced by social influences (amongst other factors), where both place and time offers "freedom" for exploring, creating and experimenting with ideas (creativity). Practical implementations of Freiraum are evident in companies such as 3M with its 15\% rule [93, p. 21], Google with its 80:20 rule [94], and others such as GE and Motorola that encourage staff to engage in "bootleg" and "submarine" activities [32, pp. 124-130].

Freiraum as authorised, protected and dedicated "space" designated specifically for the exploration of new ideas, which takes the form of free time away from the usual extreme time pressures and other work, is thus one of three main organisational determinants that contributes to a fluid process of new knowledge creation identified in this study. Like Freiraum, the second determinant is also strongly tied to the work environment and can be considered a factor of organisational culture. This is the propensity of individuals to experiment with ideas, even at risk of failure i.e. whether or not staff are encouraged to develop a high degree of innovation willingness. The third determinant as identified by the wider study to which these findings contribute, is the expertise and experience of individuals. This comes from working in the thick of the action, experiencing problems and opportunities as, when and where they occur. Working in the thick of action may be conceived as the mirror image of Freiraum in that work in this "space" relies on executing establish hed knowledge only, and not experimenting with anything new. For example, assembly line workers may know from experience about problems with the production line, but while in the midst of their routine work they do not have the capacity to generate creative ideas to solve them. Instead they need focus and concentration to execute tasks efficiently. The three determinants and their relationships are shown in Figure 4. 


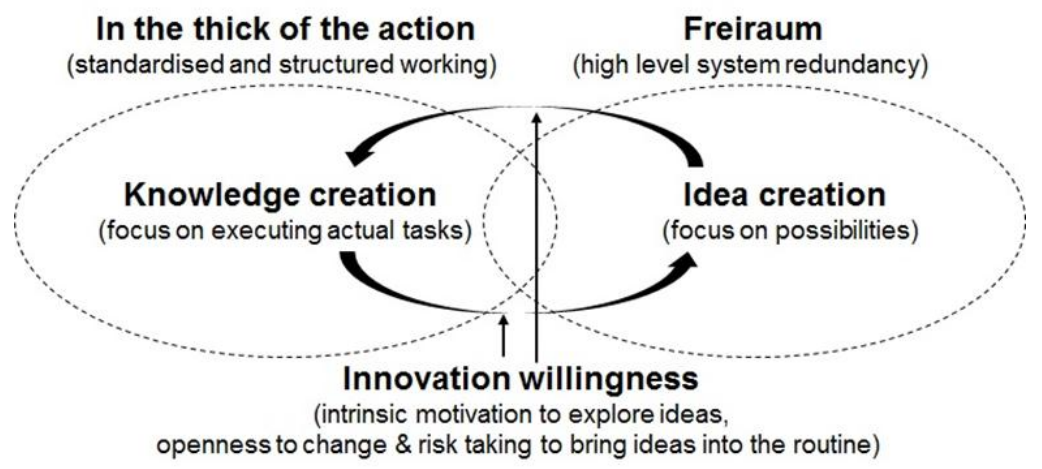

Figure 4. Three determinants that contribute to fluid process of new knowledge creation

An implication of these findings is that individuals need to be supported so that they both engage in the routine to develop their expertise and experience, and periodically step out of it in order to explore new ideas. Where this is successful, the new ideas are then brought into the routine to be shared and prototyped. When workers are involved in prototyping they are thus operating in the space between the routine (thick of the action) and idea creation (Freiraum). They contribute to new routines and practices with the expectation of innovation in products and services delivery. Of course, when a prototype (or new concept) is executed or reproduced, it eventually takes its place as routine work. An advantage of this articulation over standard models for facilitating creativity and innovation (such as linear innovation processes with shared routines and fixed structures) is that it can be adopted to fit with the extant management style of the organisation, and its own particular context. This is important given the dynamic nature of new knowledge creation, creativity and innovation.

\section{Discussion: extending our understanding of organisational culture as support for knowledge creation, creativity and innovation}

This study did not set out to test any specific model(s), such as those that incorporate the concepts of knowledge, creation and creativity as cited in Table 1 above. However, the opportunity to reconsider one in particular became evident at the data analysis stage, particularly as Patterns 3 and 4 were generated. Findings from the study presented here tie to the earlier work by Nonaka and his colleagues on the SECI model and the concept of Ba, not least because of the focus on enabling conditions that depend on characteristics of organisational culture. For example, leadership is a component of Originating $\mathrm{Ba}$, and Cyber Ba emphasises space as a prerequisite for new knowledge creation [2, pp. 4647], and both these feature strongly in the case study. Space is especially important to the concept of Freiraum as a locus for creativity and innovation.

The relationships of key components of an organisational culture that allows for innovation willing staff to move between periods of work time in the thick of the action and others of Freiraum (see Figure 4 above), also recalls Nonaka and Takeuchi's earlier discussions of systems redundancy as a facilitator of their "knowledge spiral" [1, pp. 80-82]. They argue for redundancy as a positive feature of an organisation that values overlaps in information and activities to promote the sharing of tacit knowledge across functions, teams and hierarchies. They view this as a means of speeding up knowledge creation processes, particularly at the concept development stage. However, they do not explicitly integrate redundancy into the SECI model. Rather, they provide recommendations for encouraging redundancy within organisational processes. They suggest, for example, setting up staff rotations, bringing different departments together for project work, dividing product development staff into competing teams, and making it more obvious where knowledge and information are held within the organisation. Freiraum puts an emphasis on human creativity, innovation, and encouragement of knowledge redundancy through changed perspectives, alongside recognition that staff "travel" with their work from this more creative space to other settings in the thick of the action. Thus it points to an extension the concept of Ba within the SECI model through a detailed exploration of the work on desirable conditions and processes as presented here. At the very least, this analysis goes some way to explain what is lacking in the SECI model as far as creativity is concerned. In this context Freiraum also articulates well with the broader explanations of systems redundancy and the requirement of this for innovation (for example, [56] [95, p. 105]). 
This work also responds to some of the criticisms of the extant KM literature as relevant to the theme of organisational culture. For example: it provides a level of detail that is greater than that which is presented in studies which treat organisational culture as an overarching entity or a series of listed factors; it considers relationships between factors of the organisational culture in order to explain particular processes; it takes the discussion beyond information and knowledge sharing and to the desired outputs of $\mathrm{KM}$ in the form of new knowledge creation, creativity and innovation. Also of interest here is the prominence of leadership style as a key resource of organisational culture. This gives further credence to the view that organisational culture in the context of KM may in part be a euphemism for something less palatable: power issues [11] [16]. The treatment of this theme also supports the suggestion that organisational culture might be regarded as an intangible asset of KM in its own right [4, p. 187].

Of course this work has limitations. As a single case study no claims can be made for the generalisability of the findings: the goal here was to present a "good example" [96] of phenomena at play developed using standard methods pertinent to the communication of context-specific problems and solutions [97]. The interplay of the concepts modelled here (Freiraum, and working in the thick of the action, in a context of innovation willingness) needs to be tested in other environments for its value across different contexts to be assessed. However, as an academic piece of work (and not a black box case study destined for the practitioner press) based on extensive fieldwork using triangulated data sets, this work offers a framework with implications for practice in the tradition of other detailed studies in KM, creativity and innovation management (for example, [98]).

\section{Conclusion}

It was established above that there have been calls for further work to examine the links between knowledge, innovation and performance, and to shed light on the organisational circumstances under which KM initiatives might lead to improved results [3]. This paper has responded to such calls in a new and original contribution that explores knowledge and creativity management issues related to organisational culture. Focusing on elements of the organisational macrostructure, some key relationships have been identified as pertinent to understanding how particular influences of organisational culture have an impact knowledge creation, creativity and innovation.

Organisations that seek a positive influence on processes of knowledge creation, creativity and innovation should: be open to change; encourage and value free communication and new and/or unusual ideas; tolerate mistakes; and nurture intrinsically motivated staff. Their leaders need to promote these characteristics as shared values, while challenging and empowering their staff to generate new ideas in a drive to further innovation. Three main determinants of knowledge creation and creativity processes are identified as: (1) structured "space" that creates expertise and experience of individuals while working in routine; (2) willingness to innovate, i.e. individuals' propensity to experiment with ideas, even at risk of failure; and (3) authorised and dedicated "space" designated specifically for individuals to explore new ideas, labelled here as Freiraum.

This output has both extended knowledge in the field (most notably in suggesting an adaptation to the long-established SECI model of knowledge conversion), and has opened up the opportunity for further debate in the area. Some of this will come through further papers from the larger study discussed here, currently under preparation. Future extension to the work may include consideration of the relative value of Freiraum in specific work contexts, the identification of types and characteristics of Freiraum (for example individual Freiraum versus group Freiraum), and the extent to which the findings presented here may be applicable to efforts to enhance innovation capacity at sectoral or national level.

\section{Notes}

1. The model is also known as the SECI model, from the initial letter of each of the stages.

2. "r" represents Pearson's correlation coefficient, a standardised measure of observed effect. Values between 0.3 and 0.5 represent a medium effect [92, p. 111].

3. A further article that explores all nine patterns together in detail is currently in preparation.

4. "Möglichkeit zur Entfaltung eigener Kräfte und Ideen (für eine Person oder Gruppe)" retrieved $28 \mathrm{~h}$ June 2013 from http://www.duden.de/suchen/dudenonline/freiraum.

\section{Acknowledgements}

The authors acknowledge the case study organisation, Professor Robert Raeside, and Professor George Stonehouse for their support of the study reported here. 


\section{Funding}

This research received no specific grant from any funding agency in the public, commercial, or not-for-profit sectors.

\section{References}

[1] Nonaka, I and Takeuchi, H. The knowledge-creating company: how Japanese companies create the dynamics of innovation. New York: Oxford University Press, 1995.

[2] Nonaka, I and Konno, N. The concept of "Ba": building a foundation for knowledge creation. California Management Review $1998 ; 40(3) ; 40-54$.

[3] López-Nicolás, C and Meroño-Cerdán AL. Strategic knowledge management, innovation and performance. International Journal of Information Management 2011; 31(6); 502-509.

[4] Mueller, J. The interactive relationship of corporate culture and knowledge management: a review. Review of Managerial Science 2012; 6; 183-201.

[5] Dalkir, K. Knowledge management in theory and practice. 2nd ed. Cambridge MA: MIT Press, 2011.

[6] Jashapara, A. Knowledge management: an integrated approach. 2nd ed. London: Pearson, 2011.

[7] Janssen, O. Job demands, perceptions of effort-reward fairness and innovative work behaviour. Journal of Occupational and Organizational Psychology 2000; 73; 287-302.

[8] Benson, R, Stacie, B, and Richard, B. Overcoming barriers to knowledge sharing in virtual teams. Organizational Dynamics 2007; 36(3); 259-273.

[9] Lin, $\mathrm{CH}$ and $\mathrm{Wu}$, JC. Exploring barriers to knowledge flow at different knowledge management maturity stages. Information and Management 2012; 49(1): 10-23.

[10] Alavi, M, Kayworth, TR and Leidner, D. An empirical investigation of the influence of organizational culture on knowledge management practices. Journal of Management Information Systems 2005-6; 22(3); 191-224.

[11] Hall, $\mathrm{H}$ and Goody, M. KM culture and compromise - interventions to promote knowledge sharing supported by technology in corporate environments. Journal of Information Science 2007; 33(2); 181-188.

[12] Jashapara, A. The emerging discourse of knowledge management: a new dawn for information science research. Journal of Information Science 2004; 31(2); 136-148.

[13] Kayworth, T and Leidner D. Organizational culture as a knowledge resource. In Holspapple CW (ed) Handbook on knowledge management; knowledge matters (volume 1), Berlin: Springer, 2003, pp. 233-252.

[14] Boisot, M. Knowledge assets. Oxford: Oxford University Press, 1998.

[15] Von Krogh, G and Roos, J. Organizational epistemology. New York: St Martin’s Press, 1995.

[16] Ekbia, $\mathrm{H}$ and Kling, R. 'Power in Knowledge Management in late modern times', http://ils.indiana.edu/faculty/hekbia/web/other/EkbiaKling_PowerKM.pdf (2003, accessed 10 June 2013).

[17] Detlor, B, Ruhi, U, Turel, Bergeron, P, Choo, CW, Heaton, L, and Paquette, S. The effect of knowledge management context on knowledge management practices: an empirical investigation. Electronic Journal of Knowledge Management 2006; 4(2); $117-128$.

[18] Chua, AYK and Banerjee, S. Customer knowledge management via social media: the case of Starbucks. Journal of Knowledge Management 2013; 17(2); 237-249.

[19] Nakano, D, Muniz J, and Batista, ED. Engaging environments: tacit knowledge sharing on the shop floor. Journal of Knowledge Management 2013; 17(2); 290-306.

[20] Oluikpe, P. Developing a corporate knowledge management strategy. Journal of Knowledge Management 2012; 16(6); 862878.

[21] Amin, A and Roberts, J Community, economic creativity, and organization. Oxford: Oxford University Press, 2008.

[22] Amin, A. and Roberts, J. Knowing in action: beyond communities of practice. Research Policy 2008; 37(2): 353-369.

[23] Davenport, E and Hall, H. Organizational knowledge and communities of practice. Annual Review of Information Science and Technology 2002; 36, 171-227.

[24] Hall, $\mathrm{H}$ and Graham, D. Creation and recreation: motivating collaboration to generate knowledge capital in online communities. International Journal of Information Management 2004 24(3): 235-246.

[25] Wenger, E. Communities of practice: learning, meaning, and identity. Cambridge: Cambridge University Press, 1998.

[26] Wenger, E, McDermott, RA, and Snyder, W. Cultivating communities of practice: a guide to managing knowledge. Boston, MA: Harvard Business School Press, 2002.

[27] Amabile, TM. The motivation for creativity in organizations. Boston, MA: Harvard, 1996.

[28] Amabile, TM. How to kill creativity. Harvard Business Review 1998; 76(5): 76-87.

[29] Bendixen, P. Kreativität und Unternehmensorganisation. Köln: Kiepenheuer und Witsch, 1976.

[30] Csíkszentmihályi, M. The domain of creativity. In: Runco, MA \& Albert RS (eds) Theories of creativity. Newbury Park: Sage. 1990, pp. 190-214.

[31] Csíkszentmihályi, M. Creativity: flow and the psychology of discovery and invention. New York: HarperCollins, 1996.

[32] Jaworski, J and Zurlino, F. Innovationskultur: vom Leidensdruck zur Leidenschaft; wie Top-Unternehmen ihre Organisation mobilisieren. Frankfurt am Main: Campus-Verlag, 2009. 
[33] Nooteboom, B. Learning and innovation in organizations and economies. Oxford: Oxford University Press, 2000.

[34] Sawyer, RK. Group genius: the creative power of collaboration. New York: Basic Books, 2007.

[35] Sutton, RI. Weird ideas that work: how to build a creative company. New York: Free Press, 2007.

[36] Teece, DJ. Dynamic capabilities and strategic management: organizing for innovation and growth. Oxford: Oxford University Press, 2009.

[37] Tidd, J and Bessant, JR. Managing innovation integrating technological, market and organizational change. Chichester: Wiley, 2010.

[38] Woodman, RW, Sawyer, JE, and Griffin, RW. Toward a theory of organizational creativity. Academy of Management Review 1993, 18(2): 293-321.

[39] Zhou, J and Shalley, CE. Handbook of organizational creativity. New York: Lawrence Erlbaum Associates, 2008.

[40] Grant, RM. (1996). Prospering in dynamically-competitive environments: organizational capability as knowledge integration. Organization Science 1996; 7(4): 375-387.

[41] Tsoukas, H. The firm as a distributed knowledge system: a constructionist approach. Strategic Management Journal 1996; 17: 11-25.

[42] Von Krogh, G and Roos, J. Managing knowledge: perspectives on cooperation and competition. London: Sage, 1996.

[43] Choo, CW. The knowing organization: how organizations use information to construct meaning, create knowledge, and make decisions. New York: Oxford University Press, 2006.

[44] Nonaka, I, Toyama, R, and Hirata, T. Managing flow: a process theory of the knowledge-based firm. Basingstoke: Palgrave Macmillan, 2008.

[45] Stonehouse, GH and Pemberton, JD. Learning and knowledge management in the intelligent organisation. Participation and Empowerment 1999; 7(5); 131-144.

[46] Pemberton, JD and Stonehouse, GH. Organisational learning and knowledge assets - an essential partnership. The Learning Organisation 2000; 7(4): 184-194.

[47] Pemberton, JD and Stonehouse, GH. The organizational characteristics of knowledge-centricity. In: Montano, B (ed) Innovations of knowledge management. London: IRM Press 2005, pp 99-123.

[48] Argyris, C and Schön, DA. Organizational learning II : theory, method and practice. Wokingham: Addison-Wesley, 1996.

[49] Argyris, C. On organizational learning. Oxford: Blackwell Business, 1999.

[50] Chesbrough, HW. Open innovation: the new imperative for creating and profiting from technology. Boston, MA: Harvard, 2003.

[51] Chesbrough, HW. Open business models: how to thrive in the new innovation landscape. Boston, MA: Harvard, 2006.

[52] Von Hippel, E. The sources of innovation. New York: Oxford University Press, 1998.

[53] Von Hippel, E. Democratizing innovation. Cambridge, MA: MIT Press, 2005.

[54] Prahalad, CK and Ramaswamy, V. Co-opting customer competence. Harvard Business Review 2000; 78; 79-90.

[55] Ramaswamy, V and Gouillart, FJ. The power of co-creation: build it with them to boost growth, productivity, and profits. New York: Free Press, 2010.

[56] Bakken, T, Hernes, T, and Wiik, E. An autopoietic understanding of "innovative organization". In R. Magalhães \& R. Sanchez (eds) Autopoiesis in organization theory and practice (pp. 169-182). Bingley: Emerald, (2009).

[57] Bakken, T, Hernes, T, \& Wiik, E. Innovation and organization: An overview from the perspective of Luhmann's autopoiesis. In R. Magalhães \& R. Sanchez (eds) Autopoiesis in organization theory and practice (pp. 69-88). Bingley: Emerald, (2009).

[58] Hernes, $\mathrm{T}$ and Bakken, T. Implications of self-reference: Niklas Luhmann's autopoiesis and organization theory. Organization Studies 2003; 24(9): 1511-1535.

[59] Hernes, T. Understanding organization as process: theory for a tangled world. London: Routledge, 2007.

[60] Luhmann, N. Organisation und Entscheidung. Opladen: Westdt. Verl, 2000.

[61] Maula, M. Organizations as learning systems: 'living composition' as an enabling infrastructure. London: Elsevier, 2006.

[62] Magalhães, R and Sanchez, R. Autopoiesis in organization theory and practice. Bingley: Emerald, 2009.

[63] Zeleny, M. Knowledge-information circulation through the enterprise: forward to the roots of knowledge management. Lecture Notes in Computer Science 2004; 3327: 22-33.

[64] Zeleny, M. (2006). Knowledge-information autopoietic cycle: towards the wisdom systems. IJMDM International Journal of Management and Decision Making 2006; 7(1); 3-18.

[65] Daft, RL and Weick, KE. Toward a model of organizations as interpretation systems. Academy of Management Review 1984; 9(2): 284-295.

[66] Weick, KE. Sensemaking in organizations. London: Sage, 1995.

[67] Hernes, T. The spatial construction of organization. Amsterdam: Benjamins, 2004.

[68] Hernes, T. Studying composite boundaries: a framework of analysis. Human Relations 2004 57(1): 9-29.

[69] Crang, M and Thrift, N. Thinking space. London: Routledge, 2000.

[70] Thrift, N. Re-inventing invention: new tendencies in capitalist commodification. Economy and Society 2006, 35(2): 279-306.

[71] Thrift, N. Non-representational theory: space, politics, affect. London: Routledge, 2008.

[72] Smircich, L. Concepts of culture and organizational analysis. Administrative Science Quarterly 1983; 28(3): 339-358. 
[73] Senge, PM. The fifth discipline: the art and practice of the learning organization (2nd ed). New York: Doubleday/Currency, 2006.

[74] Beer, S. The Viable system model: its provenance, development, methodology and pathology. Journal of the Operational Research Society 1984: 35(1): 7-25.

[75] Beer, S. Diagnosing the system for organizations. Chichester: Wiley, 1985.

[76] Lahtinen, J. Local social knowledge management: a case study of social learning and knowledge sharing across organizational boundaries. Journal of Information Science 2013; doi: 10.1177/0165551513481431 (accessed 12 June 2013)

[77] Beer, S. Brain of the firm ( $2^{\text {nd }}$ ed). New York: Wiley.

[78] Snowden, D. Complex acts of knowing: paradox and descriptiev self-awareness. Journal of Knowledge Management 2000; 6(2); 1-33.

[79] Whitehead, AN. Process and reality. Corrected edition (eds Griffin DR and Sherburne, DW). New York: the Free Press, 1978.

[80] Nonaka, I, Von Krogh, G, and Voelpel, S. Organizational knowledge creation theory: evolutionary paths and future advances. Organization Studies 2006; 27(8), 1179-1208.

[81] Bereiter, C. Education and mind in the knowledge age. Mahwah, NJ: L Erlbaum Associates, 2002.

[82] Engeström, Y. Innovative learning in work teams: analyzing cycles of knowledge creation in practice. In: Engeström, Y, Miettinen and R, Punamäki R-L (eds) Perspectives on activity theory. Cambridge: Cambridge University Press, 1999, pp. $377-$ 406.

[83] Gourlay, S., and Nurse, A. Flaws in the "engine" of knowledge creation: a critique of Nonaka's theory. In: Buono, AF, Poulfelt, $\mathrm{F}$ and Handelshøjskolen, $\mathrm{K}$ (eds) Challenges and issues in knowledge management. Greenwich, Conn.: Information Age, 2005, pp. 293-316.

[84] Mueller, JS, Melwani, S, and Goncalo, JA. The bias against creativity: why people desire but reject creative ideas. Psychological Science, 2012; 23(1); 13-17.

[85] West, MA. Ideas are ten a penny: it's team implementation not idea generation that counts. Applied psychology 2002; 51; 411 424.

[86] Barbour, RS. Doing focus groups. London: Sage, 2007.

[87] Alexander C, Ishikawa, S and Silverstein, M (1977). A pattern language: towns, buildings, construction. New York: Oxford University Press.

[88] Coplien, J. O. (1998). A generative development - process pattern language. In L. Rising (Ed.), The patterns handbook: techniques, strategies, and applications. Cambridge, Cambridge University Press

[89] Coplien, J. O. (2006). Organisational patterns: beyond technology to people In I. Seruca, J. Cordeiro, S. Hammoudi \& J. Filipe (Eds.), Enterprise information systems VI. Dordrecht: Springer.

[90] Giddens, A. Constitution of society: outline on the theory of structuration. Cambridge: Polity Press, 1984.

[91] Bakken, T and Hernes, T. Organizing is both a verb and a noun: Weick meets Whitehead. Organization Studies 2006; 27(11), 1599-1616.

[92] Field, AP. Discovering statistics using SPSS. London: Sage, 2005.

[93] Brand, A. Knowledge management and innovation at 3M. Journal of Knowledge Management 1998; 2:1; 17-22.

[94] Bick, J. 'The Google way: give engineers room', New York Times http://www.nytimes.com/2007/10/21/jobs/21pre.html?_r=0 (October 21 2007, accessed July 12013 )

[95] Morgan, G. Images of organization. Thousand Oaks: Sage Publications, 2006.

[96] Flyvberg, B. Making social science matter. Cambridge: Cambridge University Press, 2001.

[97] Rising, L. The patterns handbook: techniques, strategies, and applications. Cambridge: Cambridge University Press, 1998.

[98] Wang W-T and Belardo, S. The role of knowledge management in achieving effective crisis management: a case study. Journal of Information Science 2009; 35(6); 635-659. 